\title{
"She completely twisted the body language": Pandemic, parody, politics, and comedy in the era of coronavirus
}

\author{
Oluchi Gloria Ogbu*
}

\section{INTRODUCTION}

The outbreak of the infectious coronavirus disease known as COVID-19 has grown into a global pandemic. Consequently, a public health emergency was declared on January 30 (WHO, 2020). The virus has affected more than 200 countries resulting in over four million cases and close to 300,000 deaths worldwide to date (WHO, n.d). Political leaders around the world have used daily press briefings to provide coronavirus updates to the public. This article explores how two female comedians have created parodies from comments made during press briefings of President Trump of the United States and Governor Cuomo of New York State to the delight and entertainment of some people and the disgruntlement of others. This article further examines how Twitter users interacted humorously and, to an extent, politically to these parodies.

At one of his coronavirus press briefings, the President of the United States spoke about exploring the potential of injecting disinfectant and light into the body as possible cures for the coronavirus disease (MSNBC, 2020; NBC Politics, 2020). Although, in a later statement, the President said his comments had been made sarcastically (Dale, 2020; Timm, 2020), whether they were meant as sarcasm or not, they generated new conflicts and fuelled existing political tensions, such as providing a basis for political opponents to call out the President's handling of the pandemic, with House speaker Pelosi suggesting on Twitter that the President's comments reflect his and his administration's thoughts about science. Her tweet reads, "the situation we are in today is a result of Republicans' rejection of science and their duty to govern" (Pelosi, 2020). Also, the former Vice-President of the United States and the Democrat's leading presidential candidate tweeted "I can't believe I have to say this, but please don't drink bleach" (Biden, 2020). This comment made by President Trump's main political opponent in the November 2020 presidential election has already gathered more than 1.5 million likes on Twitter to date. Also, as a result of the President's musings about disinfectants, producers of disinfectants and public health officials have spoken out against ingesting cleaning products and the harm in those suggestions (Valinski, 2020; Reuters, 2020).

Consequently, \#disinfectant became a Twitter trend, generating a lot of news, debates, conflicts, and comic relief. The consequences of the pandemic lockdown include an increase in the use of social media platforms such as Twitter and TikTok, a video-sharing app. Since the lockdown, TikTok has become a popular platform through which videos are being shared on other social media networks such as Twitter, creating new celebrities amid the pandemic. Also, there is an increase in the number of users who see the videos as a viable means to keep busy and stay sane in an environment filled with unease and concern (Kale, 2020; Bhatt, 2020). Two female comedians have used the contents from President Trump's and Governor Cuomo's daily briefings on coronavirus for humour skits created with the TikTok app. The pandemic-related comedies created by Sarah Cooper, who describes herself on her Twitter account as a writer, comedian, and author based in Brooklyn NY, and Maria DeCotis, another New York-based comedian, have been retweeted by thousands of people. The parodies by these two comedians have produced many comments from those who find the videos entertaining and emotionally fulfilling and a few from those who do not see the humour in them. For example, Sarah Cooper's TikTok video posted on Twitter which she tagged How to medical has already gathered more than 16 million views, with over 400,000 likes and 16,000 comments, as well as more than 140 retweets. These incidents show how comedy is becoming viral through social media (Jones, 2019). The coronavirus pandemic has had many life-changing impacts on people, on comedy and humour, and also on those interacting with skits produced during this period.

\section{Parody, Culture, and Politics}

Apart from their role as entertainment, comedy and humour have been used as a dissident tactic against oppression (Cheurfa, 2019), a call for action, and a means to persuasively disseminate information to the public, (Becker \& Bode, 2017;

Correspondence to: Oluchi Gloria Ogbu, Arthur V. Mauro Institute for Peace \& Justice at St. Paul's College. 252-70 Dysart Road Winnipeg, MB R3T 2M6.

E-mail: ogbuo@myumanitoba.ca

To cite: Ogbu, O. G. (2020). "She completely twisted the body language": Pandemic, parody, politics, and comedy in the era of coronavirus. Journal of Community Safety and Well-Being, 5(2), 82-86. https://doi.org/10.35502/jcswb.138

@ Author(s) 2020. Open Access. This work is distributed under the Creative Commons BY-NC-ND license. For commercial re-use, please contact sales@sgpublishing.ca.

gevishING Published by SG Publishing Inc. CSRA Official publication of the Community Safety Knowledge Alliance. 
Jennings, Bramlett, \& Warner, 2019). Studies show that comedy has become an important means of learning, made more valuable and persuasive when it is processed effortfully (Jennings et al., 2019). Their use as a strategy for discussing social and political issues does not take away from the therapeutic value of comedy and humour in that they provide a sense of belonging and connection, thus serving as a form of cultural intervention for individuals within a social group (MacRury, 2012). Another advantage of comic relief is the positive element of producing laughter, which can improve physical and mental well-being, such as promoting healthy aging (Berk, 2015).

Political satire can be entertaining, educational, and a persuasive method to move the public into action (Becker \& Bode, 2017). As a form of political humour, parody can serve different functions: it can be an important feature that supports and nourishes public culture in a democratic environment, it evokes laughter through the images projected, and it can demonstrate the limitations in communication and speech (Harriman, 2008). However, as a source of awareness creation or entertainment, the impact of political comedy and humour varies (Becker \& Bode, 2017; Jennings et al., 2019). Its influence will depend on how people view and utilize political comedy-only those who value political comedy will be affected by the content, either as entertainment or information, while those who do not are unlikely to learn from or be persuaded by the content (Jennings et al., 2019).

Another unique feature of parody is that, as an imitation of or "take off" on an original work or character, it often goes on to create an entirely new work (Posner, 1992, p. 68). In the case of Cooper and DeCotis, parody allows them to bring in their own creativity through their facial and body interpretations of the original character(s) and the use of accessories. For these female comedians, "there is both a taking from ... and an injection of creativity, large or small" (Posner, 1992, p. 68). In effect, parody makes a joke of what the original character said, showing how speech can reproduce itself in ways not originally intended, which may include the use of add-ons such as exaggerated facial expressions (Harriman, 2008).

\section{Original vs Add-Ons and Response(s)}

In at least three of her skits posted on Twitter, Maria DeCotis who gives Sarah Cooper credit for the inspiration of her parodies of Governor Cuomo (DeCotis, 2020d), lip-synced to coronavirus press briefing speeches of Cuomo, and her videos have garnered support from the Twitter community including tweets and retweets from other comedians and actors (Ehrlich, 2020). In her May 1, 2020, video, titled @NYGovCuomo talking about his daughter's boyfriend, DeCotis dressed as Governor Cuomo, accessorized her parody with a knife and a bottle of wine, and also acted out the characters of the governor's daughter and the daughter's boyfriend (DeCotis, 2020a). In another video, Breaking News: Governor Cuomo learns communication skills from daughter Mariah, DeCotis also played the characters of both Cuomo and his daughter Mariah (DeCotis, 2020b). Yet again in Breaking News: Governor Cuomo talks about his daughter Michaela's adult life, her additional accessories and characters include the daughter, the boyfriend, and Cuomo smoking, eating, and flinging cigarettes (DeCotis, 2020c). Likewise, in her parodies of President Trump, Sarah Cooper's accessories include a lamp, a supposedly disinfectant bottle, and a writing board, and her parody also includes misspelling hydroxychloroquine and sniffing a marker (Cooper, 2020). In all these parodies, the words uttered by Cuomo and Trump were not altered by Cooper and DeCotis in any way.

Sarah Cooper's most popular video on Twitter to date is the one tagged How to medical which has received more than 16 million views thus far. Cooper's facial expressions have incited laughter and criticism against the President. The viral impact of this parody validates the view that comedy as a means of entertainment and sharing information with the public is made more effective by the use of social media (Jones, 2019; Jennings et al., 2019). Through her body and facial expressions, Cooper creates entertainment, but the absurdity of some of the President's speech is also made more obvious in Copper's parodies (Cooper, 2020a, 2020b). This also supports the argument that parodies can expose the limitations of speech (Harriman, 2008). Cooper's parody of Trump titled How to more cases than anybody in the world was posted on Twitter on May 14 and already has more than 8 million views. In this TikTok video, Cooper lip-syncs to President Trump's argument for why the United States has more coronavirus cases, with the obvious inferred conclusion being that the U.S. has more cases because they do more testing (Cooper, 2020b). Some tweets lauded Cooper's creative addition to the video, for example one person tweeted "I cannot believe I had to scroll this far down to find a comment about the pen sniff. Comedic gold" (Tampson, 2020), and another person tweeted "the misspelled hydroxychloroquine is a nice touch" (Paul, 2020).

The majority of responses to this video complimented Sarah Cooper. Michael DeCrow tweeted "Sarah, you are pure genius. Your clips are one of the things that I actually look forward to seeing on Twitter. Thank you for these hilarious clips. Super well done" (DeCrow, 2020). Others, however, tweeted that the President's words were taken out of context-for example, The Boss tweeted: "You guys twist his speech. What he meant is, other countries like INDIA are not showing more cases and fatalities, since they are not doing more testing, which is correct." (The Boss, 2020a)

The irony here is that this form of comedy is unique in that the comedians are neither twisting or changing the comments of President Trump and Governor Cuomo-their only addition is in their creative use of accessories and their body and facial expressions, as, in this case, marker sniffing, misspelling, and exaggerated facial expression to add context. To people who noted that these were the President's exact words, The Boss responded:

Okay, for those who are asking, this is a recorded speech and how can some one twist it, I don't deny that it's a recorded speech. But, please be educated that human brain interprets a speech, both by the spoken language and the body language. She completely twisted the body language. (The Boss, 2020b).

While this statement might seem absurd, it raises questions regarding content and understanding, that is, what was intended, what was implied, and what was interpreted. These tweets show that the impact of parodies will vary depending on the value viewers place on them (Jennings et al., 2019). Apart from showing the barriers in communication, parodying 
politicians can also confirm people's opinions about them, particularly when they disagree with or consider the subject/ character irrelevant and illogical for example, Peter Binney tweeted "You're awesomely funny. I could watch your videos on a loop and laugh for hours. Unfortunately, the parodies demonstrate just how bizarre and ignorant this President is. Thanks for what you do!" (Binney, 2020).

These images in parody also evoke other sentiments, such as the questioning of the appropriateness of such humour-which I will call Paro-com appropriateness-which also begs the question, is there an appropriate time or environment for laughter? As one person's tweet seems to imply, a pandemic outbreak is not the time: "There is no time for making people laugh I think you are just wasting your time! This virus is a big thing don't make fun of it it just makes fun of you" (Abidat, 2020). Again, the answer to the question of appropriateness depends on who is viewing and the interpretation they give to the videos. As with the parodies of Trump made by Sarah Cooper, some tweets show that people are finding the comments by Cuomo during his press briefings incredulous. Here are some of the tweets:

"wait, did he really say this!!!" (AbuSalayman, 2020)

"I would not have believed this except I saw the news conference where Governor Cuomo actually said these things. And I was thinking, what?" (Parquet, 2020)

The majority of the tweets, however, appreciate the subject and the humour in the videos (Halliday, 2020; Haley, 2020). Many find the videos of Governor Cuomo entertaining as well as emotionally uplifting:

"Sitting here going thru Twitter \& being emotionally crushed by the state of the world. Then I saw this \& I smiled \& I laughed, then, I watched it again \& I smiled \& I laughed again. Just what I needed." (Reid, 2020)

Still others cannot separate entertainment from politics (Nate, 2020):

“...His government used funds that should have purchased ventilators and PPE but did not. Federal governments taxpayer money had to bail out his state! Shameful!" (Anderson, 2020)

"In all seriousness, I'm sick of having to listen to Cuomo's happy family stories when all I want to know is if we're all going to ... die." (Gomez, 2020)

As has been argued, parody can depict the limitations of communication and speech (Harriman, 2008). It also offers an opportunity for comedians to relay original messages into which they inject their own ideas (Posner, 1992). In other words, it offers a means for comedians to share their own perspectives on issues. Sarah Cooper, for instance, takes a humorous stance on political issues, she injects her creativity into her videos to expose the limitations and highlight the absurdity of the President's arguments and speeches (Noor,
2020; Hunt, 2020). Cooper makes this stance more explicit in her own words "I look at it as taking off the emperor's clothes" (Hunt, 2020, para. 4). Lip-syncing political leaders also provides an opportunity to share her political perspectives and those of others. For example, in her interview with The Guardian, Cooper mentioned people's great dislike for the President, also stating, "I feel like we have been gaslighted for years, been told it is totally normal for a president to say things like this. It is a very validating thing to see something remind you that, no, this is actually ridiculous and we can all agree on that" (Noor, 2020, para. 11). And some agree with Copper's opinion, as some tweets seem to express (Flanagan, 2020; Melissa, 2020; Brevity, 2020).

Maria DeCotis states that her aim in making these parodies is to keep people entertained during this coronavirus outbreak, and one way she can do that is through humanizing Governor Cuomo-showing the hilarity in his speeches-but in doing this, she has also found a personal gain, an internal vigour, and liveliness (Hunt, 2020). DeCotis humanizes Governor Cuomo by parodying his coronavirus press briefing speeches, particularly the ones about his daughters, their tendency to criticize and disagree with him, which includes highlighting his flawed communication skills. While providing entertainment through parodying Governor Cuomo, DeCotis hopes to stay away from delving into politics, "I'm not really commenting on his politics. Its more this human moment he had in this international crisis" (Hunt, 2020, para. 17). But given the current global health crises and the present political climate in the United States (being an election year), can comedians and their craft afford to be free from politics? Some tweets reveal that, contrary to her intentions, her videos cannot remain free from political inferences and allegations:

"The facts are he cut medicaid in his state during a pandemic. He's a clown who deserves to lose his job." (Nate, 2020)

"I knew he was a smart man! Could we get him to run for president, he is the only person who has shown the slightest amount of intelligence in this country SINCE JFK!" (positive thinking, 2020)

The popularity of the parodies created by Sarah Cooper and Maria DeCotis demonstrates that, in times of relative peace and during a global pandemic, indeed "...people still need to laugh" as DeCotis opines (Hunt, 2020, para. 18). But it also suggests that people would always interpret the content of a comedy according to their affinity with the mode of dissemination (Jennings et al., 2019). In this case, the interpretation is that comedy and humour will always have some political inferences. This argument is made more potent during this global health crisis and the fact that it is an election year in the United States.

\section{CONCLUSION}

As outlined earlier in this article, some studies have demonstrated the many roles that comedy and humour play in everyday life, such as being a tool to create mental health awareness (Wright, Twardzicki, Gomez, \& Henderson, 2014). 
In other circumstances, people have utilized humour as a tool of resilience in times of grief (Cheurfa, 2019).

One unique feature of the parodies discussed in this article is that they are usually very short. It falls on the comedians to pack a lot of context into these videos through their creative accessories, body language, and facial expressions. Despite the length, many people find these videos very entertaining, informative, and easy to relate to, for example:

“In all seriousness, watching @MariaDeCotis@ sarahcpr videos are somehow more informative/ entertaining than the actual press briefings. Thank you for helping us get through these tough times..." (marse, 2020).

Clearly, comedians are in a position to use their medium to raise awareness about social and political issues, and even if comedians do not explicitly delve into political discourse, political views are injected through public interactions with their contents. Consequently, even if the aim of comedy and humour is laughter or entertainment, it can also have political connotations. Further, comedians have the power to decide on paro-com appropriateness, as political validity is in the power to choose; the process of deciding the content of what comedy skits to produce comes from a particular position (social or political). This article suggests that despite the many benefits, comedy and humour cannot stay free of politics, even when the aim of creating comedy skits is not always political for some comedians. To put it another way, the popular understanding is that research is political because of the researcher's interest; the argument here is that comedy and humour skits are equally political because of the comedian's interests, as interests determine the choice of character and influence the themes produced.

\section{CONFLICT OF INTEREST DISCLOSURES}

The author declares that there are no conflicts of interest.

\section{AUTHOR AFFILIATIONS}

*PhD candidate in Peace \& Conflict Studies at the Arthur V. Mauro Institute for Peace and Justice, St Paul's College, University of Manitoba, Winnipeg, MB.

\section{REFERENCES}

Abidat, Y. [YAbidat]. (2020, May 15). There is no time for making people laugh I think you are just wasting your time! [Tweet]. Retrieved from https://twitter.com/YAbidat/status/ 1261367197898690566 ? $s=20$

AbuSulayman, M. [abusulayman]. (2020, May 3). Wait, did he really say this!!! [Tweet]. Retrieved from https://twitter.com/abusulayman/ status $/ 1256993950440861696 ? s=20$

Anderson, C. [Catheri28854078]. (2020, May 5). It's funny he would watch Cuomo to ignore madness when that is what completely explains his lunacy and audacity. His government used funds that should have purchased ventilators and PPE but did not. Federal governments taxpayer money had to bail out his $s$. [Tweet]. Retrieved from https://twitter.com/Catheri28854078/ status $/ 1257849064693084160 ? s=20$

Becker, A. B., \& Bode, L. (2017). Satire as a source for learning? The differential impact of news versus satire exposure on net neutrality knowledge gain. Information, Communication \& Society, 21(4), $612-625$.
Berk, R. A. (2015). The greatest veneration: Humor as a coping strategy for the challenges of aging. Social Work in Mental Health: Humor and the Challenges of Aging, 13(1), 30-47.

Bhatt, S. (2020, April 24). The rise of TikTok amid COVID-crisis: How the app got acceptance from India's social media elite. The Economic Times. Retrieved from https://economictimes.indiatimes.com/magazines/panache/the-rise-of-iktok-amid-covid-crisis-how-the-app-got-acceptance-from-indias-social-media-elite/articleshow/75351105.cms

Biden, J. (2020, April 24). [JoeBiden]. I can't believe I have to say this, but please don't drink bleach. [Tweet]. Retrieved from https://twitter. $\mathrm{com} / J$ oeBiden/status $/ 1253751812194070529 ? \mathrm{~s}=20$

Binney, P. [Twitter@pbinney] (2020, May 15). You're awesomely funny. I could watch your videos on a loop and laugh for hours. Unfortunately, the parodies demonstrate just how bizarre and ignorant this President is. Thanks for what you do! Retrieved from https://twitter. $\mathrm{com} / \mathrm{pbinney} /$ status $/ 1261439636632678405$ ? $\mathrm{s}=20$

Brevity, S. W. [AnlronWaffle]. (2020, May 14). Hate doesn't quite capture it, but it'll do. [Tweet]. Retrieved from https://twitter.com/ AnlronWaffle/status/1260976029780381697? s=20

Cheurfa, H. (2019). Comedic resilience: Arab women's diaries of national struggles and dissident humour. Comedy Studies, 10(2), 183-198.

Cooper, S. [sarahcpr]. (2020, April 23). How to medical. [Tweet]. Retrieved from https://twitter.com/sarahcpr/ status $/ 1253474772702429189 ? \mathrm{~s}=20$

Cooper, S. [sarahcpr]. (2020, May 14). How to more cases than anybody in the world. [Tweet]. Retrieved from https://twitter.com/sarahcpr/ status $/ 1261085326887604224$ ? $s=20$

Dale, D. (2020, April 24). Fact check: Trump lies that he was being 'sarcastic' when he talked about injecting disinfectant. CNN. Retrieved from https://www.cnn.com/2020/04/24/politics/fact-checktrump-disinfectant-sarcastic/index.html

DeCotis, M. [MariaDeCotis]. (2020a, May 1). @NYGovCuomo talking about his daughter's boyfriend@andrewcuomo. [Tweet]. Retrieved from https://twitter.com/MariaDeCotis/ status $/ 1256263535686045697 ? \mathrm{~s}=20$

DeCotis, M. [MariaDeCotis]. (2020b, May 15). Breaking news: Governor Cuomo learns communication skills from daughter Mariah. [Tweet]. Retrieved from https://twitter.com/MariaDeCotis/ status/1261280617364324354?s=20

DeCotis, M. [MariaDeCotis]. (2020c, May 11). Breaking News: Governor Cuomo talks about his daughter Michaela's adult life. [Tweet]. Retrieved from https://twitter.com/MariaDeCotis/ status $/ 1259831736000827393 ? \mathrm{~s}=20$

DeCotis, M. [MariaDeCotis]. (2020d, May 3). This is so good!! So funny!! You inspired me to make a Cuomo vid!! Thank you for the inspo! . [Tweet]. Retrieved from https://twitter.com/MariaDeCotis/ status $/ 1257089506001461253 ? s=20$

DeCrow, M. [MichaelDeCrow]. (2020, May 14). Sarah, you are pure genius. Your clips are one of the things that I actually look forward to seeing on Twitter. Thank you for these hilarious clips. Super well done. [Tweet]. Retrieved from https://twitter.com/MichaelDeCrow/ status $/ 1261085999452446720$ ? $\mathrm{s}=20$

Ehrlich, B. (2020, May 13). Comedian's skit about governor Cuomo and his daughter earns praise from Colbert, Alec Baldwin. Rolling Stone. Retrieved from https://www.rollingstone.com/culture/culture-news/ cuomo-daughter-boyfriend-skit-998925/

Flanagan, T. [thereseflanagan]. (2020, May 14). Yay! Great interview, and it's true - we do hate him! He's just so inherently hateable! [Tweet]. Retrieved from https://twitter.com/thereseflanagan/status $/ 1261126515456163842 ?_{s}=20$

Gomez, A. [tazdancer]. (2020, May 16). In all seriousness, I'm sick of having to listen to Cuomo's happy family stories when all I want to know 
is if we're all going to fucking die. [Tweet]. Retrieved from https:// twitter.com/tazdancer/status/1261752044597047296? s=20

Haley, S. [hs2009]. (2020, May 13). Hilarious! Love cuomo! Most parents are in this feeling together ! Rolling on the floor laughing. [Tweet]. Retrieved from https://twitter.com/hs2009/ status/1260516973861093378? s=20

Halliday, A. [AyunHalliday]. (2020, May 11). Fantastic! This has brought so much joy to our family! [Tweet]. Retrieved from https://twitter. com/AyunHalliday/status/1259862934299324420?s=20

Hariman, R. (2008). Political parody and public culture. Quarterly Journal of Speech, 94(3), 247-272.

Hunt, E. (2020, May 16). 'People still need to laugh': how lipsyncing spoofs saved lockdown. The Guardian. Retrieved from https://www. theguardian.com/technology/2020/may/16/people-still-need-tolaugh-how-lipsyncing-spoofs-saved-lockdown

Jennings, F. J., Bramlett, J. C., \& Warner, B. R. (2019). Comedic cognition: The impact of elaboration on political comedy effects. Western Journal of Communication, 83(3), 365-382.

Jones, K. (2019, April 15). How social media is changing comedy. BBC. Retrieved from https://www.bbc.com/news/entertainment arts-46871021

Kale, S. (2020, April 26). How coronavirus helped TikTok find its voice. The Guardian. Retrieved from https://www.theguardian.com/technology/2020/apr/26/how-coronavirus-helped-tiktok-find-its-voice

MacRury, I. (2012). Humour as 'social dreaming': Stand-up comedy as therapeutic performance. Psychoanalysis, Culture \& Society, 1712), 185-203.

marse. [mak36]. (2020, May 15). In all seriousness, watching@ MariaDeCotis@sarahcprvideos are somehow more informative/ entertaining than the actual press briefings. Thank you for helping us get through these tough times. Much Red heart - Be safe y'all... [Tweet]. Retrieved from https://twitter.com/mdk36/status/126141 $9701416062979 ?_{s}=20$

Melissa. [melissalvla]. (2020, May 14). It's true. We hate DJT. His voice, his face. when his voice comes out of your mouth it's clear how deranged he is. Victory hand Red heart. [Tweet]. Retrieved from https:// twitter.com/melissalvla/status/1260979479352012801 2 s=20

MSNBC. [MSNBC]. (2020, April 23). President Trump suggests "injection" of disinfectant to beat coronavirus and "clean" the lungs at the White House daily briefing. [Tweet]. Retrieved from https://twitter. $\mathrm{com} / \mathrm{MSNBC} /$ status $/ 1253492872994852864$ ? $\mathrm{s}=20$

Nate. [NathanielLull]. (2020, May 5). The facts are he cut medicaid in his state during a pandemic. He's a clown who deserves to lose his job. [Tweet]. Retrieved from https://twitter.com/Nathaniellull/ status $/ 1257852858097008640 ? \mathrm{~s}=20$

NBC Politics. [NBCPolitics]. (2020, April 23). President Trump suggests "injection" of disinfectant to beat coronavirus and "clean" the lungs at the White House daily briefing. [Tweet]. Retrieved from https:// twitter.com/NBCPolitics/status/1253465431005945863? s=20

Noor, P. (2020, May 14). The comedian going viral for lip-syncing Trump: 'People really hate him'. The Guardian. Retrieved from https://www. theguardian.com/us-news/2020/may/14/trump-lip-sync-videomemes-sarah-cooper-tiktoks-interview

Parquet, S. [SteveParquet]. (2020, May 5). I would not have believed this except I saw the news conference where Governor Cuomo. [Tweet]. Retrieved from https://twitter.com/SteveParquet/ status $/ 1257888707987648512 ? \mathrm{~s}=20$

Paul. [pablo_honey1]. (2020, May 15). The misspelled hydroxychloroquine is a nice touch. [Tweet]. Retrieved from https://twitter.com/ pablo_honeyl/status/1261252938053419008? s=20
Pelosi, N. [SpeakerPelosi]. (2020, April 24). The situation we are in today is a result of Republicans' rejection of science and their duty to govern. \#FamiliesFirst. [Tweet]. Retrieved from https://twitter.com/ SpeakerPelosi/status $/ 1253799158391201793$ ? $s=20$

positive thinking. [positiv81867123]. (2020, May 7). I knew he was a smart man! Could we get him to run for President, he is the only person who has shown the slightest amount of intelligence in this country SINCE JFK! [Tweet]. Retrieved from https://twitter.com/ positiv81867123/status/1258433402728075264? s=20

Posner, R. A. (1992). When is parody fair use? The Journal of Legal Studies, 21111, 67-78.

Reid, P. [Dodgermom]. (2020, May 6). Sitting here going thru Twitter \& being emotionally crushed by the state of the world. Then I saw this \& I smiled \& I laughed, then, I watched it again \& I smiled \& I laughed again. Just what I needed. Thank you honey - I'm logging off twitter now so I ca. [Tweet]. Retrieved from https://twitter.com/ DodgerMom/status $/ 1258184417367019521$ ? s $=20$

Reuters. [Reuters]. (2020, April 24). Trump's coronavirus disinfectant comments are 'dangerous', doctors say, after the U.S. president said during a White House briefing that scientists should try to apply their findings to patients by inserting ultraviolet light or disinfectant. [Tweet]. Retrieved from https://twitter.com/Reuters/ status $/ 1253663258499784704$ ? $\mathrm{s}=20$

Tampson, S. L. [Spanny Lee Tampson]. (2020, May 16). I cannot believe I had to scroll this far down to find a comment about the pen sniff. Comedic gold. [Tweet]. Retrieved from https://twitter.com/Spanny Tampson/status/1261660993379282946? s=20

The Boss. [Power79646739]. (2020a, May 15). You guys twist his speech. What he meant is, other countries like INDIA are not showing more cases and fatalities, since they are not doing more testing, which is correct. He never said to reduce testing in USA, so that there will be less cases. [Tweet]. Retrieved from https://twitter.com/ Power79646739/status/1261426590753447936? s=20

The Boss. [Power79646739]. (2020b, May 17). Okay, for those who are asking, this is a recorded speech and how can some one twist it. [Tweet]. Retrieved from https://twitter.com/Power79646739/ status/1261987543450562562?s $=20$

Timm, J. C. (2020, April 24). Trump says he was being sarcastic with comments about injecting disinfectants. NBC News. Retrieved from https://www.nbcnews.com/politics/donald-trump/trump-says-hewas-being-sarcastic-comments-about-injecting-disinfectants-n 191991

Valinski, J. (2020, April 24). Lysol maker: Please don't drink our cleaning products. CNN Business. Retrieved from https://www.cnn. com/2020/04/24/business/lysol-disinfectant-trump-coronavirus/ index.html

World Health Organization (WHO). (2020, January 30). Statement on the second meeting of the International Health Regulations (2005) Emergency Committee regarding the outbreak of novel coronavirus (2019-nCoV). Retrieved from https://www.who.int/news-room/ detail/30-01-2020-statement-on-the-second-meeting-of-theinternational-health-regulations-(2005)-emergency-committeeregarding-the-outbreak-of-novel-coronavirus-(2019-ncov)

World Health Organization (WHO). (2020, n.d). Rolling updates on coronavirus disease (COVID-19). Retrieved from https://www.who. int/emergencies/diseases/novel-coronavirus-2019/events-as-theyhappen

Wright, S., Twardzicki, M., Gomez, F., \& Henderson, C. (2014). Evaluation of a comedy intervention to improve coping and help-seeking for mental health problems in a women's prison. International Review of Psychiatry, 26(4), 423-429. 